\title{
GEORADAR SURVEY OF THE BRZOZÓWKA RIVER VALLEY (NE POLAND)
}

DOI: https://doi.org/10.18509/GBP210067z UDC: 551.435.14:528.855.044(438)

\author{
Krzysztof Żurek \\ Tomasz Kalicki \\ Department of Geomorphology and Geoarchaeology, Institute of Geography and \\ Environmental Sciences, Jan Kochanowski University in Kielce, Poland
}

\begin{abstract}
The investigated meandering Brzozówka River, a left tributary of the Biebrza river, is located in NE Poland in Podlasie Voivodeship. The river flow in a wide N-S orientated tunnel valley (glacial depression) between the Goniądz and Suchowola-Janów Uplands. The valley bottom is covered by peats.

The aim of geo-radar research (GPR) was to identify the geological structure of the depression bottom, determine the peat thickness and its mineral base.

First, two main research profiles - on both sides of the river - have been defined in the GIS environment. Then they have been divided into a number of sections, each of which has known spatial coordinates. The field, where GPR profiling was performed using the Mala ProEx geo-radar with a $500 \mathrm{MHz}$ shielded antenna. The obtained data was processed in the program Ground Vision. In total, 21 echograms were obtained in the research area, with a total length of $3525 \mathrm{~m}$. The result was the creation of a GPR profile crossing the Brzozówka River Valley in the W-E orientation.

A number of anomalies at different levels have been recorded on echograms. There can be interpreted as an irregular mineral base covered with an organic layer. These anomalies may be evidence of a remnant of the Pleistocene braided river system.
\end{abstract}

Keywords: Brzozówka river valley, Biebrza river valley, GPR method

\section{INTRODUCTION}

The investigated area of the Brzozówka valley is situated in the $\mathrm{N}$ part of the Białystok Upland in Podlasie Voivodeship (Fig. 1 - A and B). The relief of the region was mainly shaped during the Warta Cold Stage and transformed in periglacial conditions during the Vistulian glaciation [1], [2].

Brzozówka (a fourth order river, left-bank tributary of Biebrza river) is an underfit river with meandering pattern (Fig. $1-\mathrm{C} ; 2-\mathrm{A}$ and $\mathrm{C}$ ). It currently flows northwards and its vast valley is filled with peat. In the Pomeranian phase of the last glaciation, this valley was one of the southern outflows of the meltwater routes (Fig. 1-B), [1]. The Pleistocene relief of the valley was shaped during the sandur spreading and was further evolved during the Late Glacial and Holocene (Fig. 1 - A and B). The controlling factors of evolution were climate change [4].

The GPR method used to determine the thickness of organic matter and the mineral substrate is very useful in the study of paleoenvironmental evolution. This method, together with verification by geological boreholes, provides a comprehensive tool for investigating changes in valley bottom environments [5], [6], [7], [8], [9]. 


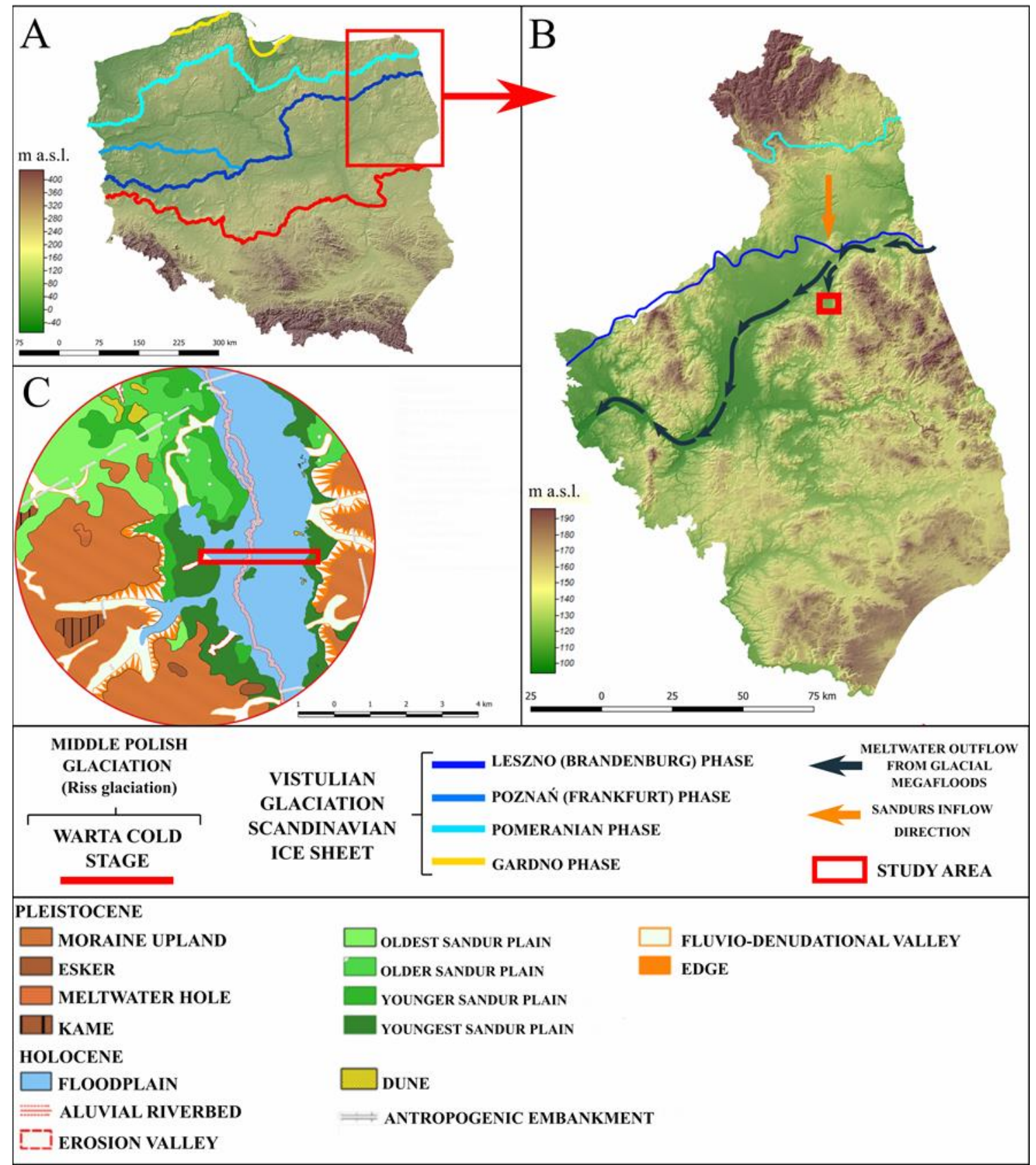

Figure 1. Location of the study. A - Hypsometric map of Poland with glaciation ranges (compiled after [2]); B - Hypsometric Map of Podlasie Voivodeship (compiled after [3]);

C - Geomorphological map of the study area

\section{AIM OF STUDY AND METHODS}

The aim of the non-invasive GPR survey was to identify the geological structure of the Brzozówka river valley depression, to determine the depth of organic sediments and to record the mineral base. This is the first stage of research to identify the origins and evolutionary stages of this valley, which has been of marginal interest to research so far. The profiles were marked out with an RTK instrument (Leica GNESS with a GS12 antenna and CS15 controller) and their exact coordinates are registered in EPSG:2179 ETRS89/Poland CS 2000 arrangement, zona 8, in Quantum GIS environment. In GPR 
surveys, the Mala GeoScience ProEx System (Professional Explorer) was used, with a frequency of pulse repetition of $200 \mathrm{kHz}$. The system was equipped with a $500 \mathrm{MHz}$ shielded antenna. The GPR profile was located in the middle part of the Brzozówka river valley. A total of 21 echograms were obtained in the study area, with a total length of $3525 \mathrm{~m}$. Profiles 0001 to 0011 are oriented $\mathrm{W}-\mathrm{E}$, while profiles $0012-0021$ are oriented $\mathrm{E}-\mathrm{W}$. The result was the creation of a GPR profile crossing the Brzozówka river valley in W-E orientation. The data obtained were processed by the Ground Vision and Reflex programs [10].

Six geological boreholes were made to verify the echograms. Sedimentological analyses were carried out using sieve and laser methods on the mineral sediments, and the content of organic matter was determined using the loss on ignition method. The results are presented graphically in GRANULOM together with the parameters of the Folk-Ward distribution calculated. Samples obtained analyzed in the Geomorphology - Hydrology Laboratory of the Institute of Geography and Environmental Sciences at Jan Kochanowski University in Kielce (Poland).

Radiocarbon dating was carried out in the Absolute Dating Laboratory in Kraków.

This article will present selected GPR profiles within which verification geological boreholes were carried out.

\section{GEOLOGICAL AND GEOMORFOLOGICAL BACKGROUND}

Three main geomorphological units dominate the landscape of the study area. To the west and east - a moraine flat glacial upland [1], [11], [12], which decrease to the flat valley of the river Brzozówka (Fig. 1: B and C). The relief was shaped during the Middle Polish (Saalian) glaciations - Warta cold stage.

The Brzozówka depression itself is probably of melt out origin [2], and its evolution should be associated with the Vistulian glaciation. It probably proceeded in two stages (Fig. 1: A and B). The first, during which periglacial conditions in the foreland formed sandur tracks (middle and upper stage) and waters flowed southwards, created a series of fluvioglacial terraces (outwash valley plains) in the Brzozówka valley [11].

The second stage occurred around 15.5-15.0 ka BP, [13] or 16.2 ka BP, when the outflow from the Narocz-Vilnius and Skidel dam lakes and the river waters of the upper Nemunas followed the valley of the Łosośna River and through the Pripilin-Nurki gorge reached the Biebrza and Narew valleys [14], [15]. This flow could also have been partly directed southwards through the Brzozówka depression and the river had a braided pattern (Fig. 1: B).

The Pleistocene relief of the Brzozówka river valley was transformed during the Late Glacial and Holocene. As a result of the stream capture, the direction of the flow was reversed and the river then began to flow in a $\mathrm{N}$ direction and discharged into the Biebrza river. This may have been caused by headward erosion, which was responsible for the lowering of the erosion base after the incision of the Biebrza River at the end of the Younger Pleniglacial. In the study section river has meandering river pattern. The Brzozówka depression is filled with peats [1]. 


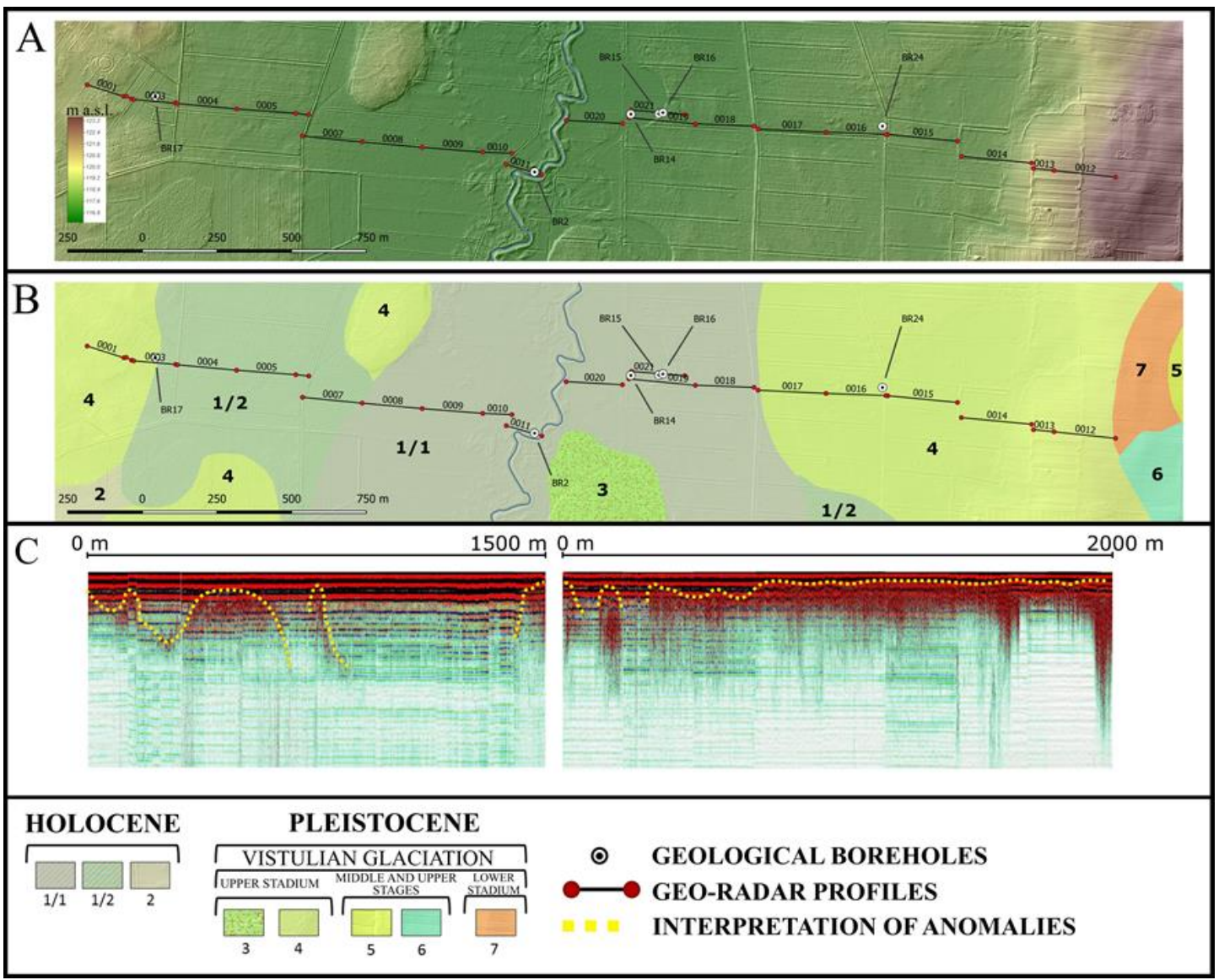

Figure 2. Location of GPR profiling in the bottom of the Brzozówka valley: A - against the DEM; B against the geological map; C - Integrated geo-radar profile with anomaly interpretation.

Legend of geological map (compiled after [1]): 1/1 - peats on glaciofluvial sands; $1 / 2$ - peats on glaciofluvial sands and gravels; 2 - peat silts; 3 - glaciofluvial sands; 4 - glaciofluvial sands and gravels; 5 - glacial sands and gravels, 6 - stagnation silts and sands, 7 - tills

\section{RESULTS}

During GPR prospection, a total of 21 echograms were obtained, with a total length of $3525 \mathrm{~m}$. The result was the creation of a GPR profile with W-E orientation crossing the Brzozówka valley (Fig 2: A and B). A number of anomalies at different levels were recorded on the echograms. The profile data can be interpreted as an irregular layer of the mineral substrate covered by organic sediments (Fig 2: C).

In purpose of verifying the GPR data, six geological boreholes were made in the segments 0002, 0011, 0019 and 0016 (Fig. 3, 4, 5 and 6). The bottom of organic sediments were also dated using the $14 \mathrm{C}$ method (Fig. 5).

In echogram 0003 over its entire length of $145 \mathrm{~m}$, a sequence of anomalies ranging in depth from 0.3 to $1.5 \mathrm{~m}$ was recorded. Interpolating their extent of occurrence, they take on a concave line representing an uneven strop. It can be interpreted as a boundary separating mineral sediments from organic matter. Confirmation is provided by borehole BR17 drilled at $77 \mathrm{~m}$ where the anomaly boundary coincides with a change in sedimentation type at $65 \mathrm{~cm}$ (Fig. 3). On this evidence, it may be assumed that the anomaly basin will be entirely filled with peats located on fluvioglacial sands and gravels which build the lower sandur level. 


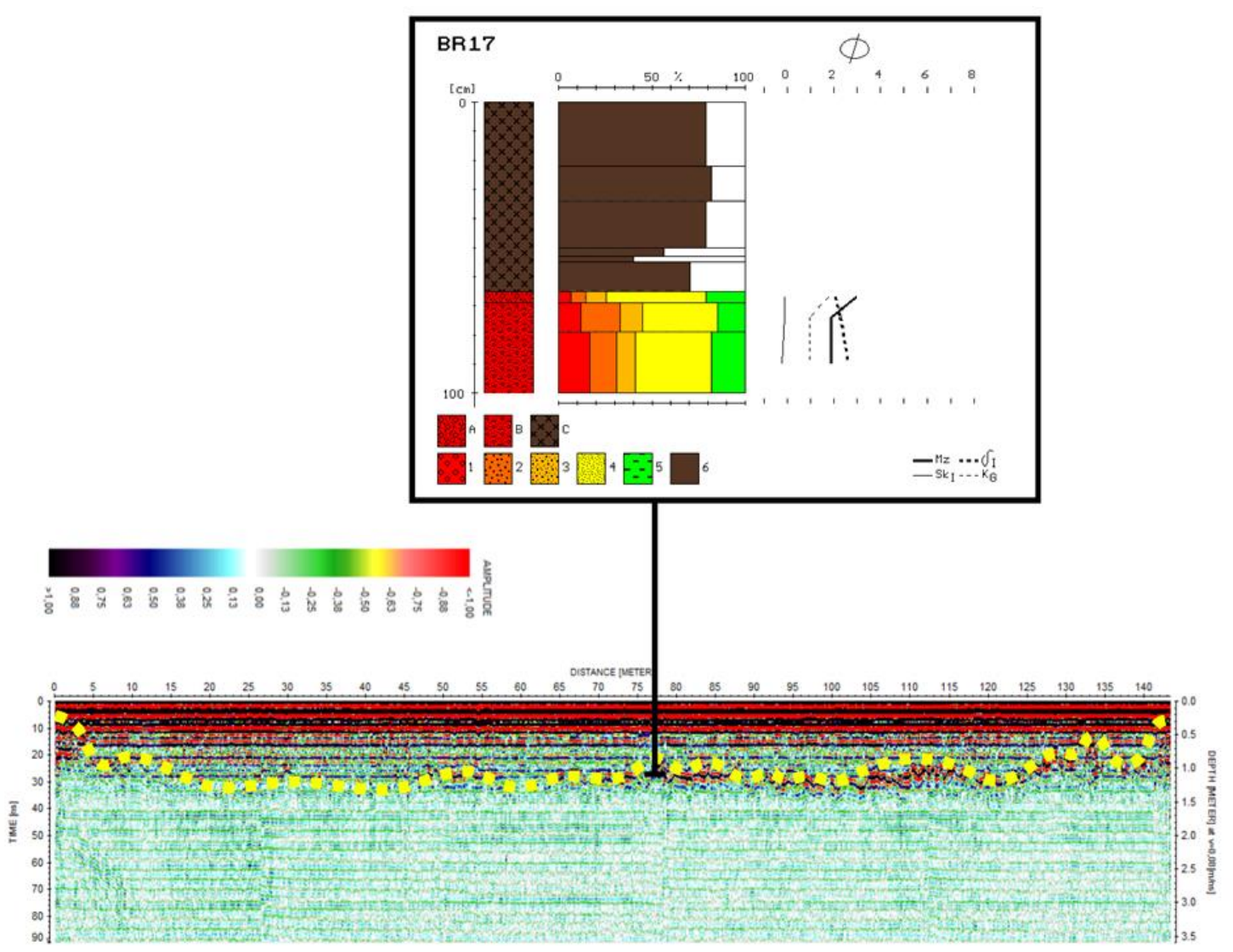

Figure 3. Echogram of profile 0003 with geological borehole BR17 Lithology:

A - sands with single gravels, B - silty sands with gravels, C - peats; Fractions: 1 - gravels, 2 - coarse sands, 3 - medium sands, 4 - fine sands, 5 - silts and clays, 6 - peats; Folk and Ward's distribution parameters; Mz - mean diameter, $\delta 1$ - standard deviation (sorting), Skl - skewness, KG - kurtosis.

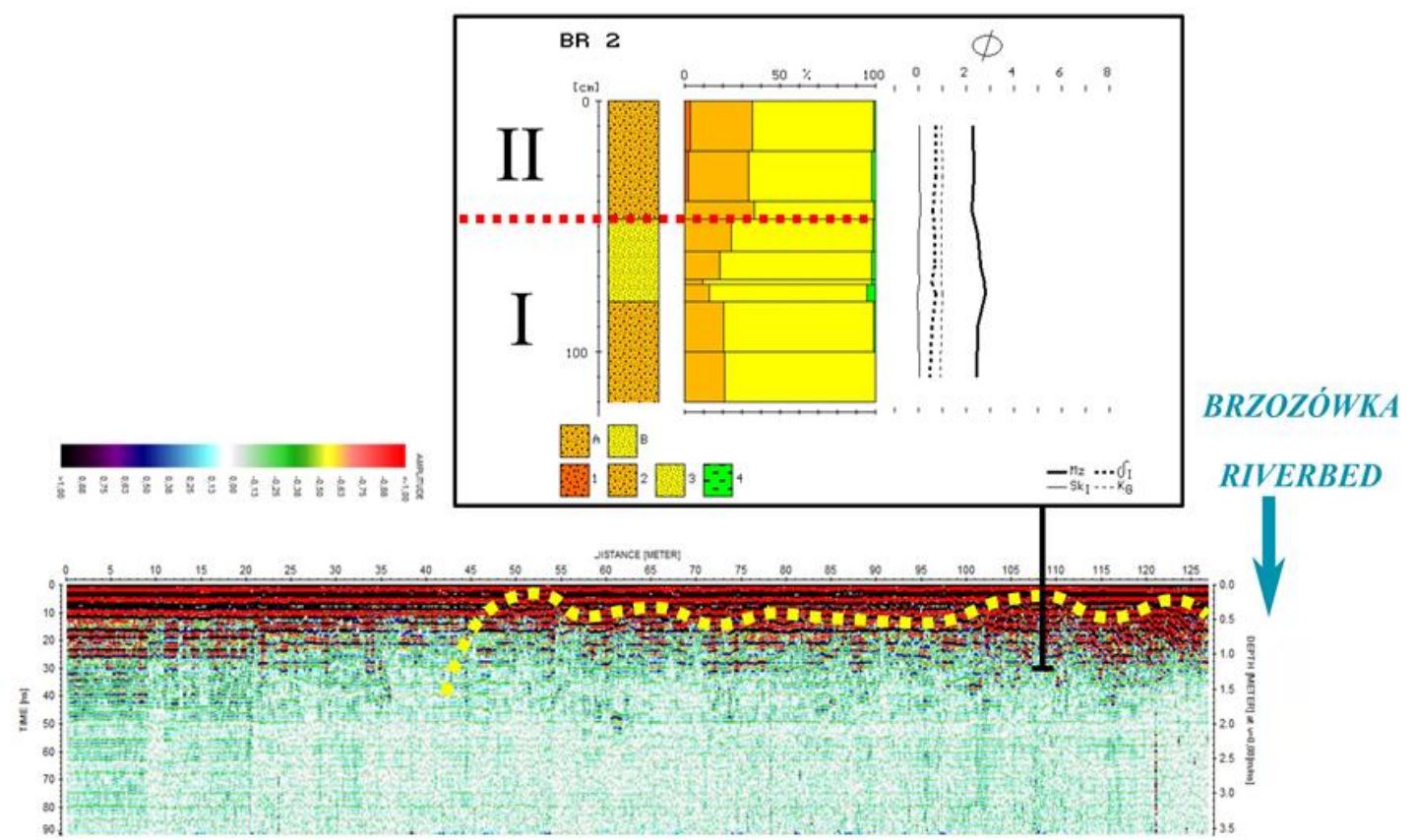

Figure 4. Echogram of profile 0011 with geological borehole BR2

Lithology: A - medium sands, B - fine sands; Fractions: 1 - coarse sands, 2 - medium sands, 3 - fine sands, 4 - silts and clays; Folk and Ward's distribution parameters; Mz - mean diameter, $\delta 1$ - standard deviation (sorting), Skl - skewness, KG - kurtosis 
In echogram 0011, located directly on the left bank of the Brzozówka River, a series of distinct linear anomalies can be distinguished, which fade out to a depth of about $45 \mathrm{~m}$. A series of anomalies from $45 \mathrm{~m}$ to $127 \mathrm{~m}$ related to a change in sedimentation type and should be interpreted as alluvium of the point bar. This is confirmed by the BR 2 borehole, which is composed of well-sorted medium and fine grain sands. It is possible to distinguish two links in it, which may testify to two episodes of alluvial aggradation. Alluvial are visible up to $45 \mathrm{~m}$. The disappearance of the anomalies at $45 \mathrm{~m}$ probably indicates a boundary between mineral deposits and organic fill (Fig. 4).

Echograms 0019 and 0016 are located on the right bank of the river. In the first of these, a strong boundary formed by the anomaly was recorded at $50 \mathrm{~m}$. This is confirmed by two geological boreholes - BR15 located beyond the anomaly boundary and BR16 located at $136 \mathrm{~m}$. The BR 15 profile will be $2 \mathrm{~m}$ deep. At $180 \mathrm{~cm}$, it borders between mineral sediments, over which peats lie directly. This is not visible in the GPR profiling. In comparison, the BR16 well consists of medium to coarse sands with no peat deposits. They are sands of fluvioglacial origin. The anomaly marks the boundary between the palaeomeander that undercut the terrace (valley sandur) (Fig. 5).

A clear line between mineral and organic sediments at $200 \mathrm{~cm}$ was recorded in the BR14 borehole. It is not visible on the echogram. The bottom of the peats was dated to: $9770 \pm 110 \mathrm{BP}$ (MKL-5082), that takes into account the probability at the level 95,4\% gives intervals 9457 - $8805 \mathrm{BC}(91,3 \%), 9551-9481 \mathrm{BC}(2,4 \%)$ and $9657-9605 \mathrm{BC}$ $(1,7 \%)$ and the probability at the level $68,3 \%$ designates the interval $9371-9123 \mathrm{BC}$ $(57,4 \%), 8997-8997 \mathrm{BC}(10,5 \%)$ and $8884-8880 \mathrm{BC}(0,4 \%)$ (Fig. 5). In the last echogram 0016, a number of anomalies were recorded along the entire length. BR24 borehole, which recorded a series of sand and gravel that builds a higher level of the Pleistocene sandur terrace (Fig. 7).

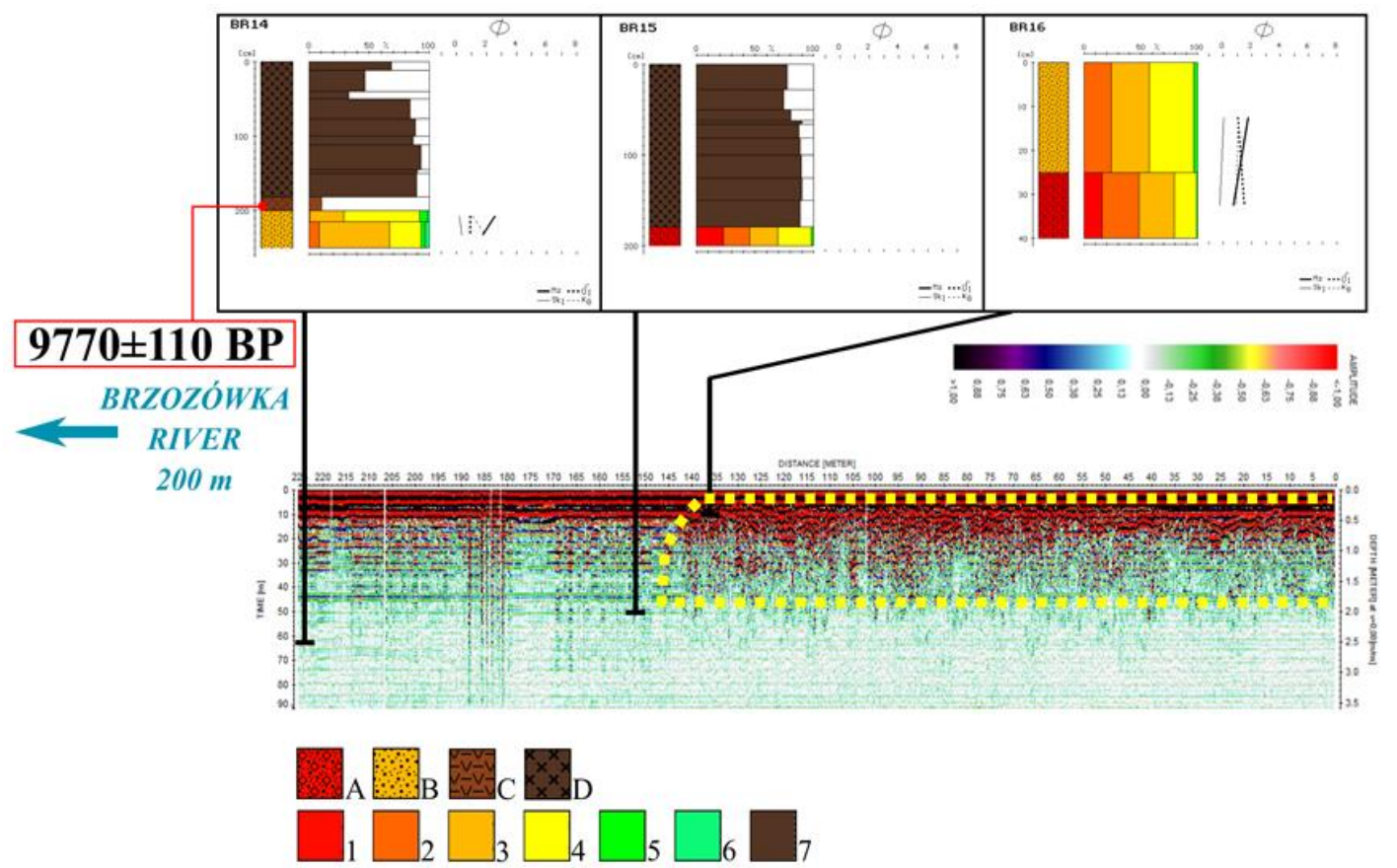

Figure 5. Echogram of profile 0019 with geological borehole BR14, BR15 and BR16 Lithology: A - sands with single gravels, B - medium - grained sands, C - peaty tills, D - peats; Fractions: 1 - gravels, 2 - coarse sands, 3 - medium sands, 4 - fine sands, 5 - silts and clays, 6 - clays, 7 - peats; Folk and Ward's distribution parameters; Mz - mean diameter, $\delta 1$ - standard deviation (sorting), Skl skewness, $\mathrm{KG}$ - kurtosis. 


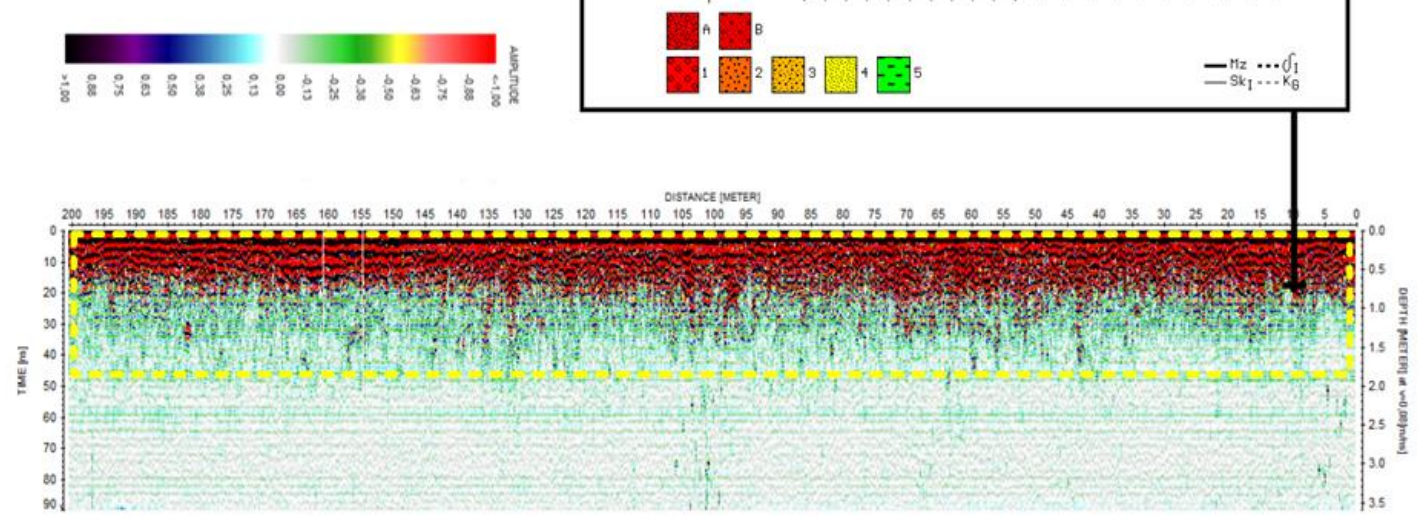

Figure 6. Echogram of profile 0016 with geological borehole BR24

Lithology: A - sands with single gravels, B - silty sands with gravels; Fractions: 1 - gravels, 2 - coarse sands, 3 - medium sands, 4 - fine sands, 5 - silts and clays; Folk and Ward's distribution parameters; Mz mean diameter, $\delta 1$ - standard deviation (sorting), Skl - skewness, KG - kurtosis.

\section{REFERENCES}

[1] Kozłowski I., Objaśnienia do szczegółowaj mapy geologicznej Polski, Arkusz Suchowola, PIG, Warszawa, 2005.

[2] Mojski J. E., Ziemie polskie w czwartorzędzie. Zarys morfogenezy, PIG, Warszawa, 2005.

[3] Weckwerth P., Wysota W., Piotrowski W., Adamczyka A., Krawieca A., Dąbrowski M., Late Weichselian glacier outburst floods in North-Eastern Poland: Landform evidence and palaeohydraulic significance, Earth-Science Reviews, Elsevier, pp 216-233, 2019.

[4] Starkel L., Paleografia holocenu, PWN, Warszawa, 1977.

[5] Frączek M., Kalicki M., Wawrusiewicz A., Sanko A.F., Kontekst środowiskowy i stratygrafia stanowiska archeologicznego Lipowo w Kotlinie Biebrzy (NE Polska), Acta Geographica Lodziensia, 107, pp 25-37, 2018.

[6] Przepióra P., Kalicki T., Chwałek S., Houbrechts G., Historyczny układ hydrotechniczny w Jędrowie (województwo świętokrzyskie) zachowany $w$ formach i osadach - studium geoarcheologiczno-konserwatorskie, ACTA UNIVERSITATIS LODZIENSIS, 29-40, Łódź, pp 29-40, 2019.

[7] Kalicki T., Chrabąszcz M., Chwałek S., Tsvirko D., Żurek K., Biesaga P., Przepióra P., New research results in the lower and middle section of the Lososina valley (Wierna Rzeka) holy cross mountains, Poland, Acta Geobalcanica, 7-1, Ohrid, pp 13-18, 2021.

[8] Lamparski P., Formy i osady czwartorzędowe w świetle badań georadarowych, Prace Geograficzne, 194, PAN IGiPZ, Warszawa, pp 115, 2004. 
[9] Lamparski P., Badania georadarowe kemów jako przykład możliwości zastosowania metod geofizycznych do badania form zbudowanych z drobnoziarnistych osadów klastycznych, Przegląd Geograficzny, 92, 3, pp 423-446, 2020.

[10] Chwałek S., Kalicki T., Krupa J., Results of ground-penetrating radar (GPR) survey of Agora. International Symposium Paphos Agora Project „In the heart of ancient city - Five years of Krakow Archaeologists' Research at the Paphos Agora on Cyprus (2011-2015), Kraków, 2016.

[11] Banaszuk H., Kotlina Biebrzańska i Biebrzański Park Narodowy, Wydawnictwo Ekonomia i Środowisko, Białystok, 2004.

[12] Kondracki J., Geografia Polski: regiony fizyczno-geograficzne, Wydawnictwo Naukowe PWN, Warszawa, 2014.

[13] Kozarski S., Deglacjacja północno-zachodniej Polski: warunki środowiska i transformacja geosystemu ( 20KA $\rightarrow 10 \mathrm{KA} \mathrm{BP})$., Dokumentacja Geograficzna 1, 1995.

[14] Kalicki T., Zapis zmian klimatu oraz działalności człowieka i ich rola w holoceńskiej ewolucji dolin środkowoeuropejskich, Prace Geograficzne IGiPZ PAN, Warszawa, pp 204, pp 348, 2006.

[15] Frączek M., Bęben A., Żurek K., Kalicki T., Wawrusiewicz A., Szypul W., Kasprzyk P., New results of the palaeoenvironmental and archaeological research of the Subneolithic huntergatherer communities of the Niemen Culture case study for Lipsk site (NE Poland), Acta Geobalcanica, 6-3, Ohrid, pp 137-144, 2020. 